\title{
Brucelloma; hepatosplenic nodules resolved with antibiotherapy
}

\author{
Bruselloma; antibiyotik tedavisi ile düzelen hepatosplenik nodül \\ Yasemin Işık Balcı*, Funda Akpınar ${ }^{* *}$, Ahmet Ergin ${ }^{* *}$, Ümmühan Torlak ${ }^{* *}$, Ali Koçyiğiti** \\ *Pamukkale Üniversitesi Tıp Fakültesi, Çocuk Hematoloji ve Onkolojisi Bölümü, Denizli \\ **Pamukkale Üniversitesi Tıp Fakültesi, Çocuk Sağlığı ve Hastalıkları Bölümü, Denizli \\ ***Pamukkale Üniversitesi Tıp Fakültesi, Radyoloji Bölümü, Denizli
}

\begin{abstract}
Liver and spleen involvement are a common finding in the course of brucellosis; however, only one pediatric case with hepatosplenic and two pediatric cases with splenic abscess formation have been reported in the literature. Splenic abscess respond to treatment with anti-biotherapy but hepatosplenic abscess need surgical drainage as well. We present a case of a fourteen-year-old girl, with both hepatic and splenic nodule formation, and was cured with just anti-biotherapy. To our knowledge, this was the first pediatric case with hepatosplenic nodule to be cured with just combination anti-biotherapy.
\end{abstract}

Pam Med J 2014;7(3):226-228

Key words: Brucelloma, childhood, antibiotherapy, hepatosplenic nodule.

\section{Özet}

Brusellozis seyri esnasında karaciğer ve dalak tutulumu sık görülmektedir ancak sadece bir vakada hepatosplenik nodül ve iki pediatrik vakada dalak apsesi olduğu bildirilmiştir. Dalak apseleri antibiyotik tedavisine yanıt vermekle birlikte hepatosplenik nodüllerin tedavisi için drenaj gereklidir. Burada ondört yaşında hepatik ve splenik nodül ile başvuran ve antibiyotik tedavisi ile tamamen düzelen bir hasta sunulmuştur. Bilgilerimize göre vakamız hepatosplenik nodül ile başvuran ve antibiyotik tedavisi ile tamamen düzelen ilk pediatrik vakadır.

Pam Tip Derg 2014;7(3):226-228

Anahtar sözcükler: Bruselloma, çocuk, antibiyotik, hepatosplenik nodul.

\section{Introduction}

Brucellosis is a zoonotic disease; its prevalence is high especially in the Mediterranean basin, Arabian Gulf, India, Mexico, and South and Central America [1]. Human infection can occur from direct contact and more frequently with consumption of raw milk and milk products. The most frequent symptoms are arthralgia and fever while the most common clinical finding is hepatosplenomegaly [2]. After clinical suspicion blood culture and Brucella-Wright titer was used for diagnosis. Particularly in endemic areas, a Wright's titer of 1:80 in suspected cases for Brucellosis can be taken as a diagnostic titer [3].

There is one pediatric case presenting with hepatosplenic abscess in the literature, cured with surgical drainage and two pediatric cases with splenic abscess that were cured with antibiotics [4-8]. As to our knowledge our case was the first pediatric patient that brucellosis causing both hepatic and splenic nodules in acute form of the disease.

\section{Case report}

A fourteen years old girl, with no history of chronic disease, was admitted to our clinic with arthralgia going on for six weeks. She lived in rural area and they made their cheese from animals that they own. Also her brother had a history of brucellosis. Her physical examination was normal except for four centimeters hepatosplenomegaly. Her laboratory investigation was as follows: C-reactive protein, $0.8 \mathrm{mg} / \mathrm{dL}(0-0.5 \mathrm{mg} / \mathrm{dl})$; White blood cells, 5950

Yasemin Işık Balcı

Yazışma Adresi: Pamukkale Üniversitesi Tıp Fakültesi, Çocuk Hematoloji ve Onkolojisi Bölümü, Denizli e-mail: dryibalci@gmail.com 
$\mu / L$ (peripheral smear; \%52 polymorphonuclear leukocytes and \%48 lymphocytes, erythrocyte morphology; hypochromia, microcytosis. No toxic granulation and no atypical cells or blasts); Platelets, $232000 \mu / \mathrm{L}$; Hemoglobin, 13,7 g/dL; Hematocrit, \%40; Erythrocyte sedimentation rate, 30/hour. There was slight elevation of liver enzymes (aspartate aminotransferase: $101 \mathrm{IU} / \mathrm{L}$; alanine aminotransferase: $108 \mathrm{IU} / \mathrm{L}$; ALP, 144IU/L), however bilirubin levels and coagulation parameters were normal. Her renal functions and electrolyte levels were also within the normal range and antinuclear antibody and anti DNA antibody were negative. Her hepatitis markers, Cytomegalovirus and Ebstein Barr virus serology was negative for acute infection whereas her brucellosis Rose Bengal Test serology was positive and Coombs' Brucella test was positive in $1 / 5120$ titer. Even though her brucellosis serology positive, blood culture was negative. Interestingly, in ultrasound scanning, at the hilum of the spleen there were two hypo echoic nodules with nine and five centimeters in diameter other than hepatosplenomegaly. Her computed tomography scan showed multiple hypodense nodules that in the fourth liver segment, seven centimeters in diameter; at the hilum of the spleen, nine centimeter in diameter being the biggest one (Figure1).

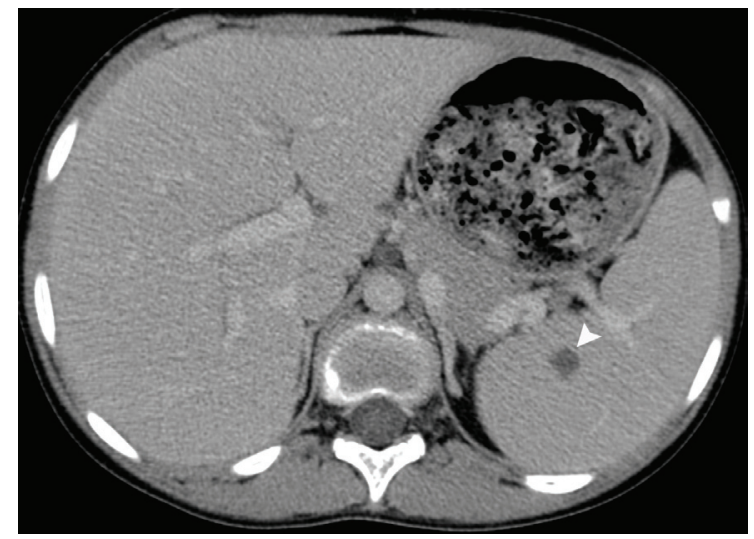

Figure 1. Axial contrast enhanced CT image shows hypodence focal lesion without contrast enhancement at the hilum of the spleen which indicates an early stage of brucellar abscess (arrow head).

The treatment was started with doxycycline (4 $\mathrm{mg} / \mathrm{kg} /$ day) and rifampicin (15 mg/kg/ day) orally. After a three week treatment, her transaminase levels returned to normal. After six weeks, in her control ultrasound scanning there was no organomegaly or liver nodule, but spleen nodule was still present with no regression in dimaension. In spite of the treatment, her brucellosis titer was also still high
(Coombs'Brucella test; 1/5120), hence amicasin (15 mg/kg/day) was added to treatment. After ten days of amino glycoside, doxycycline and rifampicin treatment, regression of spleen nodule dimension (from nine to six centimeters in diameter) was observed. Her doxycycline and rifampicin treatment were completed to six weeks and amikasin completed to two weeks. Her Coombs' Brucella test titers dropped off to 1/320 and her Rose Bengal Test was negative after three months of the treatment. At the end of six months, brucellosis agglutination tests were negative and also her liver and spleen nodules were all resolved. Her brucellosis titers and ultrasound scans were checked, but relapse was not seen.

\section{Discussion}

Microorganism can survive and multiply in mononuclear-phagocytic system cells, so it can reach lymphatic and blood stream, and then removed by reticuloendothelial system [9]. Brucellosis involves the liver from benign subclinical serum aminotransferase increase to chronic suppurative disease [10]. According to clinical presentation it can be classified as acute (0-2 months), subacute (2-12 months) and chronic brucellosis (>12 months) [2]. Especially in chronic form of the disease, liver and spleen involvement can be seen in adults as abscess, granuloma or in other words brucellosis [5]. Our patient also had hepatosplenomegaly when she administered. Our research showed only one pediatric case presented with hepatosplenic abscess in the course of infection, whose findings were seen in acute form of the disease and there is two pediatric cases presenting with splenic abscess formation [6-8]. Nodule or abscess formation was reported as chronic phase of the disease. Interestingly in our case splenic and liver nodules were detected in the acute form. There is not any definite treatment modality for brucellosis, but combination of Doxycycline and an amino glycoside seems to be the best, but addition of rifampin should be considered [4]. In our case treatment was started with doxycycline and rifampicin, but since existence of her splenic nodules and her high serological titers, amino glycoside was added to treatment, which was enough for both clinical improvement and radiological resolution of nodules.

As to our knowledge there is one pediatric brucellosis case causing hepatosplenic nodule, which was treated with combination of surgery and anti-biotherapy [6]. In addition, our case was presented with both hepatic and splenic 
abscess and cured with anti-biotherapy, which was different than other cases cured with surgical resection. In summary, although it is rare for children, hepatosplenic brucellosis can be seen in endemic areas. Antibiotherapy should be considered when a pediatric case with brucellosis is encountered.

Conflict of interest: The authors declared no conflict of interest.

\section{References}

1. Young EJ. Brucella species. In: Mandell GL, Bennett JE, Dolin R, editors. Principles and practice of infectious diseases. Philadelphia. Churchill Livingstone; 2000. p. 2386-2393.

2. Buzgan $\mathrm{T}$, Karahocagil MK, Irmak $\mathrm{H}$, et al. Clinical manifestations and complications in 1028 cases of brucellosis: a retrospective evaluation and review of the literature. Int J Infect Dis 2010;14:e469-e478.

3. A Zamani. Brucella antibody titer (Wright's test) in healthy primary school children in Tehran. Iranian J Pediatr 2013;51:687-692.
4. Ariza J, Pigrau C, Cañas C, et al. Current understanding and management of chronic hepatosplenic suppurative brucellosis. Clin Infect Dis 2001;32:1024-1033.

5. Ruiz Carazo E, Muñoz Parra F, Jiménez Villares MP, del Mar Castellano García M, Moyano Calvente SL, Medina Benítez A. Hepatosplenic brucelloma: clinical presentation and imaging features in six cases. Abdom Imaging 2005;30:291-296.

6. Vallejo JG, Stevens AM, Dutton RV, Kaplan SL. Hepatosplenic abscesses due to Brucella melitensis: report of a case involving a child and review of the literature. Clin Infect Dis 1996; 22:485-489.

7. Seçmeer G, Ecevit Z, Gülbulak B et al. Splenic abscess due to brucella in childhood. A case report. Turk J Pediatr 1995;37:403-6.

8. Parande AM, Mantur BG, Kore M, Palled E. Splenic abscess due to Brucella melitensis - A rare pediatric complication. J Lab Physicians 2010;2:105-108.

9. Spink WW. Host-parasite relationship in human brucellosis with prolonged illness due to suppuration of the liver and spleen. Am J Med Sci 1964;247:129-136.

10. Akritidis N, Tzivras M, Delladetsima I, Stefanaki S, Moutsopoulos HM, Pappas G. The liver in brucellosis Clin Gastroenterol Hepatol 2007;5:1109-1112. 